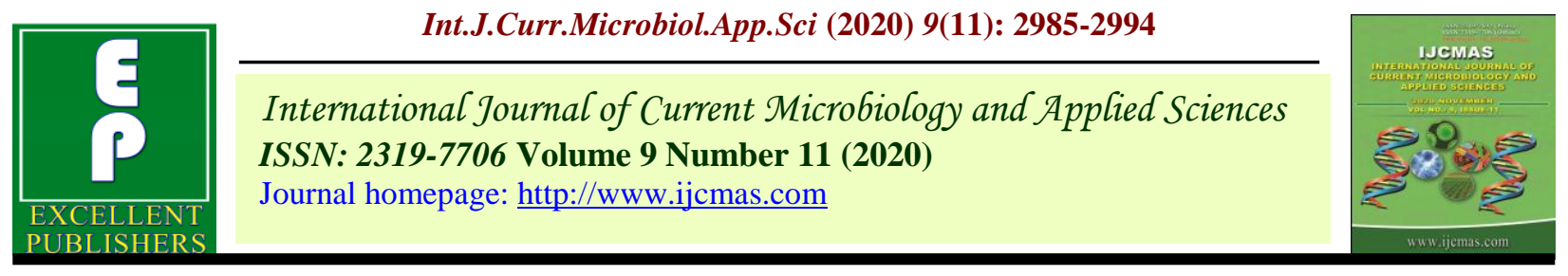

Original Research Article

https://doi.org/10.20546/ijcmas.2020.911.361

\title{
A Study on Knowledge of Homemakers Regarding Cashless Transaction
}

\author{
Ekta $^{*}$, Manju Mehta and Binoo Sehgal \\ Department of Family Resource Management, COHS, CCS Haryana Agricultural University, \\ Hisar, Haryana, India \\ *Corresponding author
}

\section{A B S T R A C T}

\begin{tabular}{|l|}
\hline Key w o r d s \\
Cashless \\
transaction, \\
$\begin{array}{l}\text { Homemakers, } \\
\text { Knowledge }\end{array}$ \\
\hline Article Info \\
\hline $\begin{array}{l}\text { Accepted: } \\
20 \text { October } 2020 \\
\text { Available Online: } \\
\text { 10 November } 2020\end{array}$ \\
\hline
\end{tabular}

Cashless economy is an economy where maximum transactions are done without using the physical cash but through digital means like credit cards, debit cards, e-wallets and electronic fund transfer (ECS, NEFT, RTGS, USSD, UPI, Aadhar based payment system etc. The major benefits of cashless economy in India are: reduced tax avoidance and money laundering, reduced costs of printing money etc. The present study was conducted in two districts i.e. Hisar and Bhiwani of Haryana state with objectives to assess the level of knowledge about cashless transaction and to identify the reasons for use of cash by homemakers. Two wards each was randomly selected from both district headquarter. From each selected ward 50 homemakers having their own bank account were selected purposively through snowball technique. 100 working \&100 non-working homemakers were selected thus, total 200 homemakers were selected. A pretested interview schedule was used to collect data. The results showed that (95.0\%) among working respondents and (78.0\%) among non-working respondents used cash because cash is widely acceptable. All the respondents had knowledge about cashless transaction. Forty eight percent working respondents and $62.0 \%$ non-working respondents and $55.0 \%$ of total respondents were of the opinion that help of someone is required in cashless transaction.

\section{Introduction}

Cash is a basic necessity for humans without which survival is not possible. In India majority of the payments are made in cash as notes and coins. The prime minister of India, on 8th November, 2016 demonetized the two largest denominations of currency notes of INR 500 and INR 1000, which were ceased with immediate effect with a few exceptions. The entire nation was in a state of shock because such a huge render was declared invalid in just one announcement and it was not the first time the government of India has taken such a step. Indian government took this step in 1946 and 1978 but in 2016 it faced a lot of criticism as people were left with only INR 100 notes or less denomination to transact with. The main aim of this step was aimed to attack on counterfeit currency, currency used for terrorist financing, black money and corruption. Less than 5 percent of total payments electronically. Illiterate people do not know how to use digital transactions. Financial literacy and awareness about cash less transactions is paramount in India to 
make the cashless economy. Cashless Economy refers to the term where the physical flow of currency notes and coins are replaced with digital flow of money, which includes use of plastic money. Plastic money involves the use of plastic cards such as debit cards, credit cards, pre-paid cards, contact less cards etc. Electronic payment modes include all kinds of mobile wallets and payments made through smart phones, laptops etc.

The present study was conducted with the objectives to identify the reasons for use of cash by homemakers and to assess the level of knowledge about cashless transaction.

\section{Review of literature}

Podile and Rajesh (2017) found that majority of the respondents $(72.82 \%)$ felt that convenience in transaction is the reason for cashless payments followed by $64.61 \%$ felt that incentives encourage people to avail cashless transactions, $59.49 \%$ felt that transaction procedures complicate cashless payments, $53.33 \%$ respondents felt that lack of technical knowledge is the obstruction for cashless transactions and $52.82 \%$ respondents felt that transaction costs discourage cashless payments.

Rajanna (2018) revealed that $100 \%$ of the respondents used Debit, Credit cards and ATMs, $93.33 \%$ of the respondents used mobile banking, $90 \%$ of the respondents used RTGs and $85.33 \%$ NEFT. 63.33 percent of the respondents used net-banking, $56.66 \%$ of the respondents used POS and 52\% of the respondents used digital wallets. Reaming respondents expressed their opinion as: control Black money $(60 \%)$, control corruption $(56.66 \%)$, control illegal activities $(50 \%)$ and other benefits $(40 \%)$.

Dominic et. al (2018) reported that $58 \%$ of respondents used cash as a medium of exchange whereas $42 \%$ used cashless way as medium of exchange in the Indian economy. Only 44\% respondents used cash as a medium of exchange because of the convenience they have in using cash whereas $26 \%$ used cash because of the security they have in using cash, 14\% used cash because it is easy to bargain using cash, whereas $16 \%$ used cash because they do not have much knowledge towards digital transactions.

Gajjar (2019) studied that credit/debit card was used by majority (34\%) of respondents followed by $23 \%$ respondents who preferred E- wallet mobile for mode of payment, $17 \%$ respondents preferred net banking, 15\% respondents preferred cash and least $11 \%$ respondents preferred cheque for mode of payment. Cashless payment system was adopted by majority (37\%) of respondents because of its convenience followed by $25 \%$ respondents adopted because of discounts/cash back rewards and $19 \%$ respondents adopted because of shortage of currency notes and easy tracking of expenditure.

\section{Materials and Methods}

Hisar and Bhiwani districts from Haryana state were selected randomly. Two wards each were randomly selected from both the district headquarters. In Hisar city ward 16 and ward 20 and in Bhiwani city ward 1 and ward 31 were randomly selected. From each selected ward 50 homemakers having their own bank account were selected through snowball technique. So, from each district headquarter. 100 homemakers were selected in such a way that 50 were working and 50 were non- working homemakers. Thus, the total number of respondents was 200 homemakers.

Data were collected personally by researcher through interview schedule. The respondents 
were informed about the purpose of the study clearly.

\section{Results and Discussion}

\section{Personal and demographic variables}

Personal and demographic attributes of the working and non-working respondents were studied for proper interpretation of the findings and are presented in table 1.

\section{Age}

Table 1 shows that majority of the working respondents i.e. $57.0 \%$ belonged to the age group 36-48 years and in the case of nonworking respondents $67.0 \%$ belonged to age group 36-48 years. In total sample majority of the respondents $(62.0 \%)$ were in the age group of 36-48 years.

\section{Marital status}

Data revealed that hundred percent of working and non-working respondents were married. No respondent was single/ divorcee/ separated in both the categories i.e. working and non-working respondents.

\section{Family type}

Majority of the working and non-working respondents belonged to nuclear family $(98.0 \%)$ each, followed by joint type of family $(2 \%)$ each for working and nonworking respondents. In totality a thumping majority $(98.0 \%)$ were having nuclear family, followed by joint family $(2.0 \%)$

\section{Family size}

Maximum working respondents $(81.0 \%)$ and non-working respondents $(90.0 \%)$ had family size of 4-6 members. Eighteen percent working and $8.0 \%$ non-working respondents were having 1-3 members. Few working (1.0\%) and non-working $(2.0 \%)$ respondents were having large family of 7-9 members. Overall huge majority $(85.5 \%)$ had 4-6 members.

\section{Monthly family income}

Income wise distribution has been presented in table 1 and showed that among working respondents, 40 per cent had monthly family income of Rs. 60,001-90,000/-, followed by Rs.30,001-60,000/- (30.0\%) and up to Rs $30,000 /-(30.0 \%)$.

In non-working respondents, monthly income of 45 per cent families was reported up to Rs.30,000/-, followed by Rs. 30,001-60,000/(35.0\%) and Rs. 60,001-90,000/- (20.0\%). In total sample $37.5 \%$ had monthly income up to Rs. 30,000/-. One third of the respondents had their monthly family income of Rs. 30,001$60,000 /-$ and $30 \%$ had between Rs. 60,001$90,000 /-$.

\section{Family education status}

Table 1 depicts the family education status of the respondents. It was found that majority of working $(86.0 \%)$ and non-working $(78.0 \%)$ respondents had medium family education status. Only $14.0 \%$ working respondents had high family education status. Not a single working respondent had low family education status whereas $22.0 \%$ of non-working respondents were from low family education status. Overall family education status was medium (82.0\%), low (11.0\%) and high $(7.0 \%)$

\section{Reasons for use of cash}

Reasons for the use of cash by the respondents have been presented in table 2 and fig. 1 Majority of the working respondents $(95.0 \%)$ and non-working 
respondents $(78.0 \%)$ used cash because cash is widely acceptable, followed by $73.0 \%$ of working and $92.0 \%$ of non-working respondents who were using cash as they thought that cash payment is the only option. Sixty eight percent of working respondents and $83.0 \%$ of non-working respondents were using cash as it offers greater privacy. Personal preference was the reason for use by $50.0 \%$ of working and $65.0 \%$ of non-working and $49.0 \%$ of working respondents and $91.0 \%$ of non-working respondents were using cash as cashless payment system is not available everywhere. In complete sample majority of the respondents $(86.5 \%)$ used cash because cash is widely accepted, followed by $82.5 \%$ who used cash as they thought cash payment is the only option; $75.5 \%$ were using cash as greater privacy was offered by cash; $70.0 \%$ were using cash because cashless payment system is easy to use and $57.5 \%$ were using because of personal preference.

\section{Knowledge of respondents about cashless transaction}

Table 3 presents the knowledge about cashless transaction of working and nonworking respondents. All the respondents had knowledge about cashless transaction. Forty eight percent working respondents and $62.0 \%$ non-working respondents and $55.0 \%$ of total respondents were of the opinion that help of someone is required for cashless transaction. Sixty three percent working and $46.0 \%$ nonworking respondents and $54.5 \%$ of total sample highlighted that credit/ debit card is required for cashless transaction. Seventy eight percent working respondents, $99.0 \%$ non-working respondents and $88.5 \%$ of aggregate sample were of the opinion that it is better to read terms and conditions of cashless transaction before proceeding. Eighty percent working respondents, $76.0 \%$ non-working respondents and $78.0 \%$ of total sample had knowledge that card details can be stored on phone or laptop. Ninety seven percent working respondents, all non-working respondents and $98.5 \%$ of overall sample believed that use of cashless transaction gives satisfaction.

Thirty percent working, $51.0 \%$ non-working respondents and $40.5 \%$ of total sample had apprehension that problems may arise in conducting cashless transaction. Cashless transaction is expensive to buy goods \& a service was considered by $68.0 \%$ of working, $87.0 \%$ of non-working and $77.5 \%$ of total sample. Seventy nine percent of working, $63.0 \%$ of non-working and $71.0 \%$ of total sample realized that cashless transaction is fast \&convenient, whereas $93.0 \%$ of working, $71.0 \%$ of non-working and $82.0 \%$ of total sample had knowledge that it saves time.

\section{Level of knowledge about cashless transaction}

Table 4 and fig. 2 show the level of knowledge of working and non-working homemakers. $48.0 \%$ of working respondents and $22.0 \%$ of non-working respondents had high level of knowledge about cashless transaction, followed by $29.0 \%$ of working and $54.0 \%$ of non-working with medium level of knowledge whereas, $23.0 \%$ of working and $24.0 \%$ of non-working respondents had low level of knowledge about cashless transaction. In overall sample, $23.5 \%, 41.5 \%, 35.0 \%$ had low, medium, high level of knowledge about cashless transaction respectively.

\section{Correlation of method of payment used and independent variables}

Table 5 depicts the correlation of method of payment used with age, family type, number of family members, family education status, family income, socio economic status and mass media exposure. 
In working respondents, correlation was highly significant with socio economic status, mass media exposure, family income, age, number of family members. However, low level of correlation was with family type and family education status.

In non-working respondents, correlation was highly significant with family income, family education status, socio economic status, mass media exposure and age, and correlation was low with number of family members. Whereas, there was no significant correlation between method of payment used and family type.

In total respondents, correlation was highly significant with family income, socioeconomic status, age, mass media exposure and number of family members. Family education status and family type had low level of correlation.

Table.1 Personal profile of the respondents

\begin{tabular}{|c|c|c|c|c|c|}
\hline $\begin{array}{l}\text { Sr. } \\
\text { No }\end{array}$ & Variables & Category & $\begin{array}{l}\text { Working } \\
(n=100)\end{array}$ & $\begin{array}{c}\text { Non } \\
\text { working } \\
(n=100)\end{array}$ & $\begin{array}{c}\text { Total } \\
\text { (percent) } \\
(\mathbf{n}=\mathbf{2 0 0})\end{array}$ \\
\hline \multicolumn{6}{|c|}{ Personal and demographic variables } \\
\hline \multirow[t]{3}{*}{1.} & \multirow[t]{3}{*}{ Age( in years) } & $22-35$ & 37 & 29 & $66(33.0)$ \\
\hline & & $36-48$ & 57 & 67 & $124(62.0)$ \\
\hline & & $49-61$ & 6 & 4 & $10(5.0)$ \\
\hline 2. & Marital status & Married & 100 & 100 & $200(100.0)$ \\
\hline \multirow[t]{2}{*}{3.} & \multirow[t]{2}{*}{ Family type } & Joint & 2 & 2 & $4(2.0)$ \\
\hline & & Nuclear & 98 & 98 & 196(98.0) \\
\hline \multirow[t]{3}{*}{4.} & \multirow[t]{3}{*}{ Family size } & Upto-3members (small) & 18 & 8 & $26(13.0)$ \\
\hline & & 4-6 members (medium) & 81 & 90 & $171(85.5)$ \\
\hline & & 7-9 members (large) & 1 & 2 & $3(1.5)$ \\
\hline \multicolumn{6}{|c|}{ Socio-economic variables } \\
\hline \multirow[t]{3}{*}{1.} & \multirow{3}{*}{$\begin{array}{l}\text { Monthly family } \\
\text { income (Rs.) }\end{array}$} & Up to $30000 /-$ & 30 & 45 & $75(37.5)$ \\
\hline & & $30001-60000 /-$ & 30 & 35 & $65(32.5)$ \\
\hline & & 60001-90000/- & 40 & 20 & $60(30.0)$ \\
\hline \multirow[t]{3}{*}{2.} & \multirow{3}{*}{$\begin{array}{l}\text { Family education } \\
\text { status }\end{array}$} & Low & 0 & 22 & $22(11.0)$ \\
\hline & & Medium & 86 & 78 & $164(82.0)$ \\
\hline & & High & 14 & 0 & $14(7.0)$ \\
\hline
\end{tabular}

Personal and demographic variables 
Table. 2 Reasons for use of cash by the respondents

\begin{tabular}{|l|l|c|c|c|}
\hline $\begin{array}{l}\text { Sr. } \\
\text { No }\end{array}$ & Reasons for use of cash & $\begin{array}{c}\text { Working } \\
(\mathbf{n = 1 0 0})\end{array}$ & $\begin{array}{c}\text { Non-Working } \\
(\mathbf{n = 1 0 0})\end{array}$ & $\begin{array}{c}\text { Total } \\
(\mathbf{n = 2 0 0})\end{array}$ \\
\hline 1. & Cash is widely accepted & 95 & 78 & $173(86.5)$ \\
\hline 2. & Cash payment is the only option & 73 & 92 & $165(82.5)$ \\
\hline 3. & Cash offer greater privacy & 68 & 83 & $151(75.5)$ \\
\hline 4. & Personal preference & 50 & 65 & $115(57.5)$ \\
\hline 5. & $\begin{array}{l}\text { Cashless payment system is easy to } \\
\text { use }\end{array}$ & 49 & 91 & $140(70.0)$ \\
\hline
\end{tabular}

Frequency is same as percentage for working and non-working respondents

Table.3 Knowledge about the cashless transaction

\begin{tabular}{|c|c|c|c|c|c|c|c|}
\hline \multirow[t]{2}{*}{$\begin{array}{l}\text { Sr. } \\
\text { No }\end{array}$} & \multirow[t]{2}{*}{ Level of knowledge } & \multicolumn{2}{|c|}{$\begin{array}{l}\text { Working } \\
(\mathrm{n}=\mathbf{1 0 0})\end{array}$} & \multicolumn{2}{|c|}{$\begin{array}{l}\text { Non- } \\
\text { Working } \\
(\mathbf{n}=\mathbf{1 0 0})\end{array}$} & \multicolumn{2}{|c|}{$\begin{array}{l}\text { Total } \\
(200)\end{array}$} \\
\hline & & Yes & No & Yes & No & Yes & No \\
\hline 1 & $\begin{array}{l}\text { Know about cashless } \\
\text { transaction }\end{array}$ & 100 & - & 100 & - & $200(100.0)$ & - \\
\hline 2 & $\begin{array}{l}\text { Help of someone is required } \\
\text { for cashless transaction }\end{array}$ & 48 & 52 & 62 & 38 & $110(55.0)$ & $90(45.0)$ \\
\hline 3 & A credit/ debit card is needed & 63 & 37 & 46 & 54 & $109(54.5)$ & $91(45.5)$ \\
\hline 4 & $\begin{array}{l}\text { Better to read terms and } \\
\text { conditions of cashless } \\
\text { transaction before proceeding }\end{array}$ & 78 & 22 & 99 & 1 & $177(88.5)$ & $23(11.5)$ \\
\hline 5 & $\begin{array}{l}\text { Card details can be stored on } \\
\text { phone or laptop }\end{array}$ & 80 & 20 & 76 & 24 & $156(78.0)$ & $44(22.0)$ \\
\hline 6 & $\begin{array}{l}\text { Cashless transaction gives } \\
\text { satisfaction }\end{array}$ & 97 & 3 & 100 & - & $197(98.5)$ & $3(1.5)$ \\
\hline 7 & $\begin{array}{l}\text { Problems arise in conducting } \\
\text { cashless transaction }\end{array}$ & 30 & 70 & 51 & 49 & $81(40.5)$ & $119(59.5)$ \\
\hline 8 & $\begin{array}{l}\text { Expensive to buy goods } \\
\text { through cashless transaction }\end{array}$ & 68 & 32 & 87 & 13 & $155(77.5)$ & $45(22.5)$ \\
\hline 9 & Fast and convenient & 79 & 21 & 63 & 37 & $142(71.0)$ & $58(29.0)$ \\
\hline 10 & Saves time & 93 & 7 & 71 & 29 & $164(82.0)$ & $36(18.0)$ \\
\hline
\end{tabular}

Figure in parenthesis indicates percentage

Frequency is same as percentage for working and non-working respondents 
Table.4 Level of knowledge about cashless transaction of working and non-working homemakers

\begin{tabular}{|l|c|c|c|}
\hline Level of knowledge & Working $(\mathbf{n = 1 0 0})$ & Non-working $(\mathbf{n}=\mathbf{1 0 0})$ & Total $(\mathbf{n}=\mathbf{2 0 0})$ \\
\hline Low & 23 & 24 & $47(23.5)$ \\
\hline Medium & 29 & 54 & $83(41.5)$ \\
\hline High & 48 & 22 & $70(35.0)$ \\
\hline
\end{tabular}

Figure in parenthesis indicates percentage.

Frequency is same as percentage for working and non-working respondents.

Table.5 Correlation of method of payment used and independent variables

\begin{tabular}{|l|c|c|c|}
\hline Independent variable & $\begin{array}{c}\text { Method of payment } \\
\text { (Working) }\end{array}$ & $\begin{array}{c}\text { Method of payment } \\
\text { (Non-working) }\end{array}$ & $\begin{array}{c}\text { Method of } \\
\text { payment (Total) }\end{array}$ \\
\hline Age & $0.60^{* *}$ & $0.39^{* *}$ & $0.48^{* *}$ \\
\hline Family type & $0.28^{* *}$ & $0.10 \mathrm{NS}$ & $0.18^{* *}$ \\
\hline No. of family members & $0.56^{* *}$ & $0.35^{* *}$ & $0.44^{* *}$ \\
\hline $\begin{array}{l}\text { Family education } \\
\text { status }\end{array}$ & $0.25^{* *}$ & $0.69^{* *}$ & $0.32^{* *}$ \\
\hline Family Income & $0.62^{* *}$ & $0.76^{* *}$ & $0.65^{* *}$ \\
\hline Socio economic status & $0.67^{* *}$ & $0.45^{* *}$ & $0.50^{* *}$ \\
\hline Mass media exposure & $0.65^{* *}$ & $0.41^{* *}$ & $0.45^{* *}$ \\
\hline
\end{tabular}

**Significant at $1 \%$ level of significance

NS- Non significant

Fig.1 Reasons for use of cash by the respondents

\begin{tabular}{|c|c|c|c|c|c|c|}
\hline 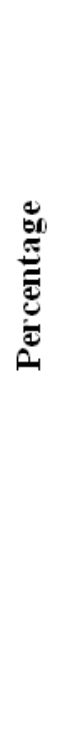 & $\begin{array}{r}100 \\
90 \\
80 \\
70 \\
60 \\
50 \\
40 \\
30 \\
20 \\
10 \\
0\end{array}$ & $\begin{array}{c}\text { Cash is widely } \\
\text { accepted }\end{array}$ & $\begin{array}{l}\text { Cash payment is } \\
\text { the only option }\end{array}$ & $\begin{array}{l}\text { Cash offer greater } \\
\text { privacy } \\
\text { Reasons for Us }\end{array}$ & $\begin{array}{l}\text { Personal } \\
\text { preference } \\
\text { of Cash }\end{array}$ & $\begin{array}{l}\text { Cashless payment } \\
\text { system is not } \\
\text { available } \\
\text { everywhere }\end{array}$ \\
\hline
\end{tabular}


Fig.2 Level of knowledge about the cashless transaction

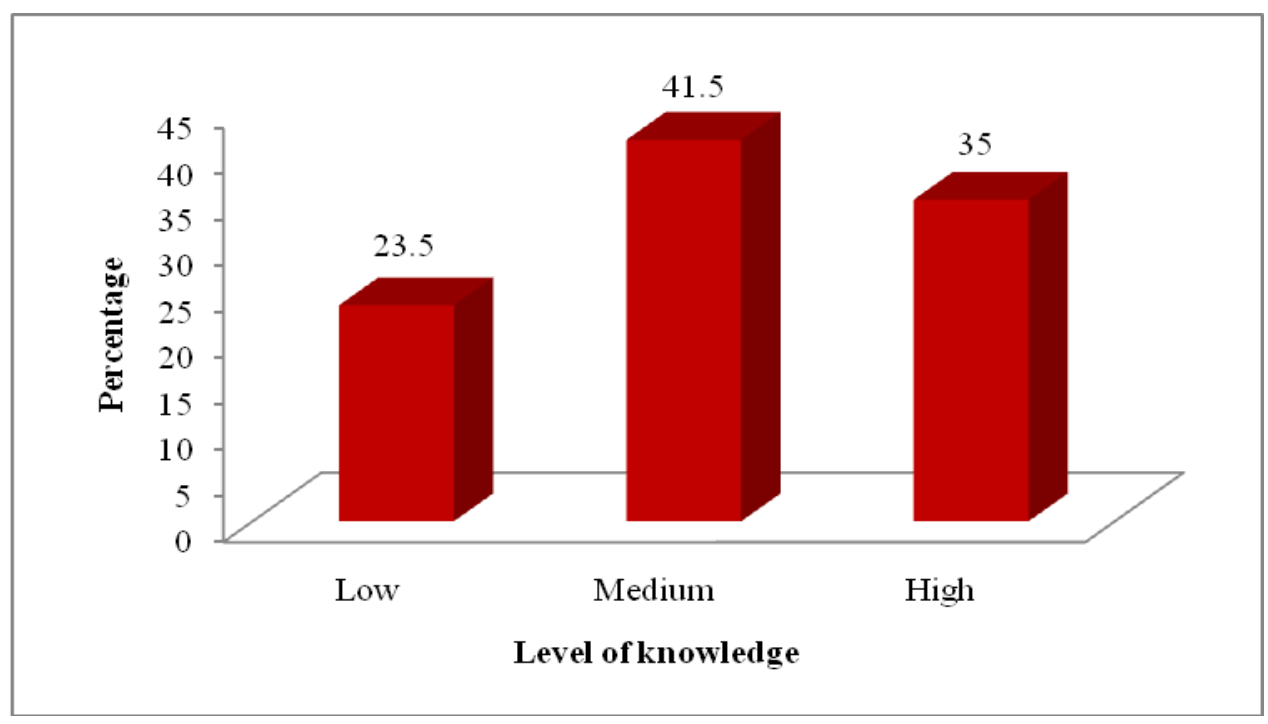

\section{Profile of the respondents}

It was found that $62.0 \%$ respondents belonged to middle age (36-48 years) cent percent were married, $98.0 \%$ were having nuclear family and $85.5 \%$ of respondents had 4-6 members in the family. Monthly income of $37.5 \%$ of respondents was up to Rs. 30,000.Family education status of 82per cent respondents was medium.

\section{Reasons for use of cash by the respondents}

A vast majority of the respondents used cash because cash was widely accepted and they thought that cash payment was the only option. Three fourth were using cash as greater privacy was offered to avoid overspending and $57.5 \%$ were using because of personal preference. Thabani (2018) found that most economic agents in Zimbabwe were not willing to fully embrace the cashless economy because the cashless payment facilities were not available everywhere, especially in rural areas. $96 \%$ of the respondents who opined that cashless platforms were not available everywhere and therefore they were not willing to embrace the cashless economy revolution. Hence cash was used mainly because of its wider acceptability and only option for the payment. Gajjar (2019) studied that credit/debit card was used by majority (34\%) of respondents followed by $23 \%$ respondents who preferred E- wallet mobile for mode of payment, $17 \%$ respondents preferred net banking, 15\% respondents preferred cash and least $11 \%$ respondents preferred cheque for mode of payment. Cashless payment system was adopted by majority (37\%) of respondents because of its convenience followed by $25 \%$ respondents adopted because of discounts/cash back rewards and 19\% respondents adopted because of shortage of currency notes and easy tracking of expenditure.

\section{Knowledge about the cashless transaction}

All the respondents had knowledge about cashless transaction. Kokila and Devi (2017) also reported that nearly $85 \%$ of males had more awareness about the cashless transaction than the females. A thumping majority (98.5\%, 88.5\% and $82.0 \%)$ believed that cashless transaction gives satisfaction, it is better to read terms and conditions of cashless transaction before proceeding and it saves 
time. Three fourth had knowledge that card details can be stored on phone or laptop it is fast \&convenient and is expensive. Little more than half of total respondents were of the opinion that help of someone is required for cashless transaction $(55.0 \%)$ and credit/ debit card is required (54.5\%). Two fifth of the respondents had apprehension that problems may arise in conducting cashless transaction. Sharma (2017) also found the awareness about the E-Payment in different educational scenarios. In primary education, only $14.28 \%$ respondents were aware about E- payment, in secondary education (11.47\%), in graduate $(58.33 \%)$ and $43.75 \%$ of post graduate respondents were aware about the mode of E-Payment. In urban area $47.61 \%$ respondents and in rural area $25 \%$ respondents were aware about the mode of $\mathrm{E}$ Payment. Online mode of payment was used by $35.84 \%$ male and $38.88 \%$ female. $33.07 \%$ respondents in age group of 15-30, 53.84\% respondents in 30-50 age group and 50\% respondents in age group of above 50 were aware about the mode of E-payment. As per occupation, employee $(58.13 \%)$, business $(11.11 \%)$, student $(33.33 \%)$ and housewife $(16.66 \%)$ used the mode of E-Payment.

Overall majority of respondents had medium (41.5\%) level of knowledge followed by high $(35.0 \%)$, and low $(23.5 \%)$ level of knowledge about cashless transaction. This may be due to the fact that medium family education status was found for majority of the respondents. Whereas, Garg and Panchal (2017) reported that $88 \%$ of the respondents had high degree of awareness regarding cashless economy in India.

In conclusion, majority of the respondents were in the age group of 36-48 years and family education status was medium. Mostly respondents used cash because cash is widely accepted. All the respondents had knowledge about cashless transaction and overall sample believed that use of cashless transaction gives satisfaction. Correlation was highly significant with family income, socioeconomic status, age, mass media exposure and number of family members.

\section{Suggestions}

Government of India should try to educate people about the benefits of going cashless before taking any crucial steps.

People should try and use any digital payment method.

People should be educated adequately. The use of ATM cards should be described to the people so that they can easily use the card.

Buyers and sellers both should be made aware about the benefits of the cashless transactions.

Proper infrastructure should be developed in the remote areas so that this facility should be taken to the rural and remote India.

\section{References}

Dominic, A., Saranya, K. and Rajani, K.G. 2018. A Study on Transformation in Behaviour of Individuals towards Cashless Economy. International Journal of Pure and Applied Mathematics, 118 (18): 1365-1372.

Gajjar, K.N. 2019. Study of Cashless Economy of India. International Journal of multidisciplinary educational research, 8(6): 2277-7881

Garg, P. and Panchal, M. 2016. Study on introduction of cashless economy in India 2016: Benefits \& Challenge's. IOSR Journal of Business and Management, 19 (4): 116-120.

Goel, R., Sahai, S., Vinaik, A. and Garg, V. Moving from Cash to Cashless Economy: A Study of Consumer Perception towards Digital Transactions. International Journal of 
Recent Technology and Engineering (IJRTE) 8(1): ISSN: 2277-3878.

Kokila, V. and Devi, U. 2017. A study on consumer behavior on cashless transaction in U.T of Puducherry. Kaav International Journal of Economics, Commerce \& Business Management, 4(2) 207-216.

Rajanna, K.A. 2018 Perception and Awareness of Customer Towards Cashless Transaction; A Case Study. International Journal of Application or Innovation in Engineering \& Management (IJAIEM) 7(3): ISSN
$2319-4847$.

Sharma, S. 2017. Study of awareness about EPayment among the people of Indore (Urban as well as Rural Area). Asian Journal of Management, 8(4): 11961202.

Venkateswararao Podile and P. Rajesh 2017. Public Perception on Cashless Transactions in India Asian Journal of Research in Banking and Finance 7(7) pp. 63-77. ISSN 2249-7323.

\section{How to cite this article:}

Ekta, Manju Mehta and Binoo Sehgal. 2020. A Study on Knowledge of Homemakers Regarding Cashless Transaction. Int.J.Curr.Microbiol.App.Sci. 9(11): 2985-2994. doi: https://doi.org/10.20546/ijcmas.2020.911.361 